\title{
Pilocarpine accumulation on Pilocarpus pennatifolius tissue culture
}

\author{
Luisa de Andrade Salles, Silvia de Oliveira Lopes, José Angelo S. Zuanazzi, \\ Sandra B. Rech, Amélia Terezinha Henriques*
}

Faculdade de Farmácia, Universidade Federal do Rio Grande do Sul

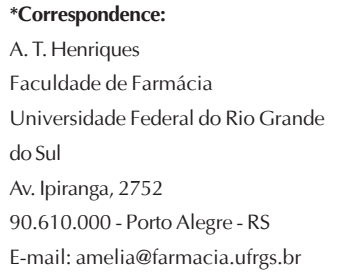

Callus and cell suspension cultures were established from young leaves of Pilocarpus pennatifolius on Murashige \& Skoog (MS) medium supplemented with $5.0 \mathrm{mg} / \mathrm{L}$ 2,4-dichlorophenoxyacetic acid (2,4-D) and $1.0 \mathrm{mg} / \mathrm{L}$ kinetine. The pilocarpine contents of callus and cell suspension cultures were quantitatively compared by $H P L C$.
Uniterms:

- Pilocarpus pennatifolius

- Pilocarpine

- In vitro cultures

- HPLC

\section{INTRODUCTION}

The imidazole alkaloid pilocarpine has been used traditionally in the treatment of glaucoma as well as to relieve the signs and symptoms of postradiation xerostomia (Anderson, Cowle, 1968; Greenspan, Daniels, 1987). It has also been used for patients with Sjögrens syndrome and other inflammatory disorders (Nusair, Rubinow, 1999) and when administered orally, increases salivary flow in patients with graft-versus-host disease due to allogenic bone-marrow transplantation (Nagler, Nagler, 1999).

Pilocarpine is found in "jaborandi" leaves of various species of Pilocarpus (Rutaceae) which grow as small trees or shrubs in South America (Bruneton, 1993). When freshly dried, the leaves yield 0.5 to $1.0 \%$ of total alkaloids. However, even under ideal storage conditions, the leaves lose at least half of their alkaloid content in one year through deterioration. Plant cells cultures are an attractive alternative source to whole plant for the production of highvalues secondary metabolites (Ramachandra Rao, Ravinshankar, 2002) and a one possible solution to obtain pilocarpine. With this aim we are investigating the establishment and the alkaloid production in cultured tissues of Pilocarpus pennatifolius, commonly known as "jaborandi-do-norte", which is native to forests from South East to South Brazil (Matos et al., 1990).

\section{MATERIALS AND METHODS}

\section{Callus and cell suspension cultures}

Young leaves from a tree of the Botanical Garden (Porto Alegre, Brazil) were thoroughly washed with tap water, surface sterilized in $70 \% \mathrm{EtOH}$ for $1 \mathrm{~min}$, rinsed twice with sterile distilled water, immersed in $1.5 \%$ sodium hypochloride for $10 \mathrm{~min}$ and rinsed four times with sterile distilled water. Callus tissue was induced on MS medium (Murashige, Skoog, 1962) containing $30 \mathrm{~g} / \mathrm{L}$ sucrose and supplemented with different 2,4-D (0, 2.5 and $5.0 \mathrm{mg} / \mathrm{L})$ and kinetin $(0,0.5$ and $1.0 \mathrm{mg} / \mathrm{L})$ concentrations. The $\mathrm{pH}$ of the medium was adjusted to 5.7 with $1 \mathrm{~N} \mathrm{NaOH}$ and agar added at $7 \mathrm{~g} / \mathrm{L}$ before autoclaving for $20 \mathrm{~min}$ at 121 ${ }^{\circ} \mathrm{C}$. The cultures were maintained at $25 \pm 1{ }^{\circ} \mathrm{C}$, under a 16 $\mathrm{h}$ photoperiod provided by cool white fluorescent lamps (45 mmol. $\left.\mathrm{m}^{-2} \cdot \mathrm{s}^{-1}\right)$. After 8 weeks the callus material was transferred to fresh medium.

Suspension cultures were initiated by transferring friable callus to the same basal liquid medium. After the cultures acquired a homogeneous appearance, the subculturing was performed every 14 days. The culture was incubated on an orbital shaker (100 rpm) in the same conditions as callus cultures. 


\section{Growth analysis}

Growth curves were determined by inoculating $5.0 \mathrm{~g}$ FW of $P$. pennatifolius cells into a $250 \mathrm{~mL}$ flask containing $50 \mathrm{~mL}$ of liquid medium. Fresh weight was measured from $5 \mathrm{~mL}$ aliquots after removing the culture medium by filtration through a pre-weighted filter paper under gentle suction. The dry weight was estimated after the sample was dried at $60^{\circ} \mathrm{C}$ for $48 \mathrm{~h}$. The specific growth rate $(\mu)$ and the doubling time $\left(\mathrm{t}_{\mathrm{d}}\right)$ during exponential phase were calculated using the exponential growth rate equation (Pirt, 1975). Three experiments were performed independently, not allowing a statistical analysis.

\section{Extraction of alkaloids}

Callus and suspension cultures were freeze dried, finely ground and kept at $-20{ }^{\circ} \mathrm{C}$. The extraction of alkaloids was carried out according to methods reported by Batista et al. (1996).

\section{HPLC conditions}

For the HPLC analysis, aliquots were loaded onto a Waters system (Millipore) fitted with a 3.9 x $150 \mathrm{~mm}$ Novapack $\mathrm{C} 18(4 \mathrm{~mm})$ column, preceded by a guard column, eluted isocratically at $1 \mathrm{~mL} / \mathrm{min}$ with $\mathrm{MeOH}: \mathrm{KH}_{2} \mathrm{PO}_{4} 5 \%$, 3:97 (V/V) adjusted to a $\mathrm{pH} 2.5$ with $\mathrm{KH}_{2} \mathrm{PO}_{4}$. Eluting compounds were monitored with a Alliance Systems 2690, software Millenium (v. 2.15.01) and Waters 996 photodiode array detector with recorded absorbance between 200 and $400 \mathrm{~nm}$ every 1.2 seconds with $4.8 \mathrm{~nm}$ of resolution. The chromatograms were extracted with absorbance at $225 \mathrm{~nm}$.
Pilocarpine (MERCK) was used as external standard; $10 \mathrm{mg}$ was dissolved in methanol, diluted stepwise $(1.0,0.5,0.25$, $0.125,0.0625$ and $0.03125 \mathrm{mg} / \mathrm{mL})$, and $10 \mu \mathrm{L}$ portions were injected into the HPLC in triplicate. The calibration plots were generated by measuring their respective peak area.

\section{RESULTS AND DISCUSSION}

The best medium for callus growth was supplemented with $5.0 \mathrm{mg} / \mathrm{L} 2,4-\mathrm{D}$ and $1.0 \mathrm{mg} / \mathrm{L}$ kinetin. After a period of six subcultures, a light-green to yellowish coloured friable callus was obtained.

A typical growth curve of the $P$. pennatifolius suspension cultures is shown (Figure 1). With $5 \mathrm{~g} / \mathrm{L} \mathrm{dwt}$ inoculum, the culture cycle was completed in approximately 20 days and the maximum dwt $35 \mathrm{~g} / \mathrm{L}$ was reached on day 19 . The specific growth rate $(\mu)$ and the doubling time (td) during exponential growth phase were found to be $0.008 \mathrm{~h}^{-1}$ and $87 \mathrm{~h}$ respectively.

The imidazolic nucleus was characterized according to the classical method described in the Brazilian Pharmacopoeia (1988).

The alkaloidal fraction of callus and suspended cells showed a peak about 8 minutes in the chromatogram at 225 $\mathrm{nm}$, at same retention time of the standard pilocarpine and with the same UV spectra. For confirmation, the standard pilocarpine was co-injected with the alkaloid fractions. In comparison with the calibration curve and external standard, the callus cultures and suspended cells accumulated an average of $1.01 \mu \mathrm{g} / \mathrm{g}$ and $0.045 \mu \mathrm{g} / \mathrm{g}$ dry weight of pilocarpine, after 30 and 19 days of growth, respectively.

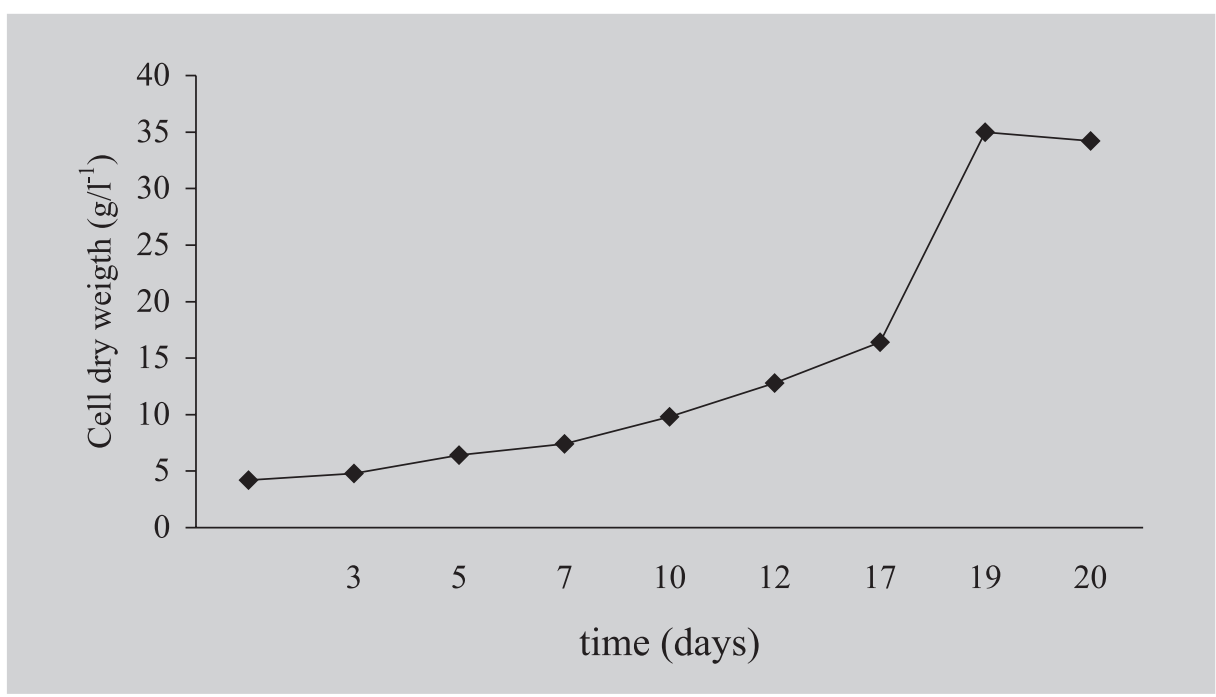

FIGURE 1 - Pilocarpus pennatifolius growth kinetics in MS medium with $5.0 \mathrm{mg} / \mathrm{L}$ of 2,4-D and $1.0 \mathrm{mg} / \mathrm{L}$ of kinetine. 
Plant cell cultures have been considered to be an attractive source of biologically active compounds. However, in some cultures, the spectrum of compounds produced by plant cell cultures can differ considerably both quantitatively and qualitatively from that found in the mother plant (Verpoorte et al., 1998). Our results show that $P$. pennatifolius tissues can be successfully grown on artificial media and maintain pilocarpine production in the cultures.

\section{RESUMO}

\section{Acúmulo de pilocarpina em culturas de tecidos de Pilocarpus pennatifolius}

Culturas de calos e de células em suspensão foram estabelecidas a partir de folhas jovens de Pilocarous pennatifolius em meio Murashige \& Skoog (MS) suplementado com $5 \mathrm{mg} / \mathrm{L}$ de ácido 2,4diclorofenoxiacético e $1 \mathrm{mg} / \mathrm{L}$ de cinetina. O teor de pilocarpina nas culturas e suspensões celulares foi quantitativamente comparado por CLAE.

UnItermos: Pilocarpus pennatifolius; Pilocarpina; Culturas in vitro; CLAE.

\section{ACKNOWLEDGEMENTS}

The authors want to thank Christina K. Gonçalves for technical assistance. The work was sponsored by CNPq and FAPERGS, Brazil.

\section{REFERENCES}

ANDERSON, T. A.; COWLE, J. B. Influence of $\mathrm{pH}$ on the effect of pilocarpine on aqueous dynamics. Brit. $J$. Ophtalmol,Bristol, v. 52, p. 607-609, 1968.

BRUNETON, J. Pharmacognosie - Phytochimie, Plantes Médicinales. 2. ed. Paris: Tec Doc., 1993. p. 859-861.

BATISTA, C.V.F.; SCHRIPSEMA, J.; VERPOORTE, R.; RECH, S.B.; HENRIQUES, A.T. Indole alkaloids from Rauwolfia sellowii. Phytochem., Oxford, v. 41, n. 3, p. 969-973, 1996.
FARMACOPÉIA BRASILEIRA. 4. ed. São Paulo: Atheneu,1988. Suplemento 1, item 42, 1996.

GREENSPAN, D.; DANIELS, T.E. Effectiveness of pilocarpine in postradiation xerostomia. Cancer, Bristol, v. 59, p. 1123-1125, 1987.

NUSAIR, S.; RUBINOW, $A$. The use of oral pilocarpine in xerostomia and Sjögren's Syndrome. Semin. Arthritis. Rheum., Boston, v. 28, p. 360_364, 1999.

NAGLER, R.M.; NAGLER, A. Pilocarpine hydrochloride relieves xerostomia in chronic graft-versus-host disease: a sialometric study. Bone Marrow Transplant, Auckland, v. 23, p. 1007-1011, 1999.

MATOS, F.J.A.; LESS, W.; BORGER-PAPENDORF, C.; GUNIA, W.; MACKENBROCK, U.; SUPER, E. Bioactive compounds from plants. New York: Wiley, 1990. 254 p. (Ciba Foudation Symposium 154).

MURASHIGE, T.; SKOOG, F. A revised medium for rapid growth and bioassays with tobacco tissue cultures. Physiol. Plant, Rockville, v. 15, p. 473-497, 1962.

PIRT, S.J. Principles of microbe and cell cultivation. New York: Wiley, 1975. p. 66-68.

RAMASHANDRA RAO, S.; RAVISHANKAR, G.A. Plant cell cultures: chemical factories of secondary metabolites. Biotechnol. Adv., Leiden, v. 20, p. 101-153, 2002.

VERPOORTE, R.; VAN DER HEIJDEN, R.; TEN HOOPEN, H.J.G.; MEMELINK, G. Metabolic engineering for the improvement of plant secondary metabolite production. Plant Tiss. Cult. Biotechnol., Leiden, v. 4, p. 3-19, 1998.

Recebido para publicação em 04 de agosto de 2003. Aceito para publicação em 08 de outubro de 2004. 